JURNAL ILMIAH ELEKTRONIKA DAN KOMPUTER, Vol.13, No.1, Juli 2020, pp. 134 - 151

p-ISSN : $\underline{1907-0012}$ (print)

e-ISSN : 2714-5417 (online)

http://journal.stekom.ac.id/index.php/elkom

page 134

\title{
SISTEM PENILAIAN KINERJA TENAGA PENDIDIK DAN TENAGA KEPENDIDIKAN BERBASIS WEB DI STEKOM SEMARANG
}

Arsito Ari Kuncoro ${ }^{1}$,Eko Haryono ${ }^{2}$, Paulus Hartanto ${ }^{3}$

${ }^{12}$ Program Studi Sistem Komputer - Sekolah Tinggi Elektronika dan Komputer (STEKOM)

${ }^{3}$ Program Studi Teknik Elektronika - Sekolah Tinggi Elektronika dan Komputer (STEKOM)

J1. Majapahit 605 Semarang- Telp/Fax: 024-6717201-02

\section{ARTICLE INFO}

Article history:

Received 1 Mei 2020

Received in revised form 22 Mei 2020

Accepted 30 Mei 2020

Available online 9 juli 2020

\begin{abstract}
STEKOM College which has branch campuses in several places. Employee performance appraisals are carried out by superiors and branch campus coordinators using Ms. Excel. The results of the performance assessment are sent to the staffing department via e-mail. The personnel department will recap the results of the performance appraisal to be conveyed to the leadership. This assessment process takes a long time and tends to be inefficient. In this study, a web-based Employee Performance Appraisal System was developed that can be accessed online by relevant appraisers at the central campus and STEKOM branch campuses. The System Development Method uses a Research and Development (R\&D) approach. Assessment elements include 6 (six) aspects, namely: Service Orientation, Integrity, Commitment, Discipline, Cooperation and Leadership. The results of the performance appraisal of educators (lecturers) apart from being used internally as a measurement of lecturers' work behavior, can also be used externally for the assessment of work behavior when the lecturer makes Employee Performance Targets (SKP), as well as being used to assess the performance of education personnel. System modeling uses the Unified Modeling Language (UML). Making the source code program using the Hypertext Preprocessor (PHP) programming language with a web-based MySQL database using Notepad ++ software. The results obtained from the use of the employee performance appraisal system, performance reports can be obtained more quickly, making it easier for the staffing department to obtain data on employee performance appraisals effectively and efficiently.
\end{abstract}

Keywords : Penilaian Kinerja, SKP, Metode R\&D, UML

\section{Pendahuluan}

Kinerja dalam sebuah perusahan maupun organisasi merupakan sebuah hal yang penting dalam memberi jawaban atas berhasil atau tidaknya tujuan dan target yang akan dicapai oleh perusahaan tersebut. Sumber Daya Manusia (SDM) merupakan faktor kunci yang paling penting dalam keberhasilan suatu institusi atau perusahaan. Setiap pegawai dalam institusi/perusahaan perlu dikelola dengan benar, agar masing-masing pegawai bisa bekerja secara tepat dan optimal. Untuk itu

Received mei 22, 2020; Revised mei 30, 2020; Accepted juli 9, 2020 

dibutuhkan suatu cara untuk mengukur kinerja setiap pegawai pada kurun waktu tertentu biasanya dalam perode satu tahun sekali yaitu Penilaian Kinerja Pegawai. Hal ini dilakukan agar manajemen bisa mengevaluasi hasil kerja pegawai pada kurun waktu tertentu serta bisa menempatkan pegawai pada posisi yang tepat, ataupun untuk pertimbangan dalam mempromosikan pegawai pada jabatan yang lebih tinggi.

Di era ini dimana teknologi informasi dan komunikasi (TIK) telah berkembang sangat pesat, setiap orang sudaah menggunakan gadget untuk mencari informasi, berkomunikasi atau sekedar mencari hiburan seperti melihat youtube bermain game, transaksi serta belanja online dan sebagainya. Demikan halnya koneksi internet pada saat ini sudah tersedia luar biasa di kota-kota dan bahkan menjangkau daerah-daerah pedesaan dan sebagaianya. Koneksi internet berbasis WiFi, bisa diakases menggunakan gadget, sehingga semua orang bisa menikmati kemudahaan dalam mencari segala sesuatu di internet. Secara umum Teknologi Informasi Komunikasi (TIK) sudah digunakan secara meluas pada berbagai aspek operasional di berbagai aktivitas kehidupan seperti di bidang pemerintahan, perdagangan, industri, kesehatan dan masih banyak yang lain termasuk pada bidang pendidikan. Dalam bidang pendidikan TIK merupakan kebutuhan yang sangat penting guna menunjang kegiatan operasional sehari-hari, yang bisa membuat pekerjaan menjadi lebih efektif dan efisien. Penggunaan TIK berbasis web pada bidang pendidikan telah digunakan di hampir semua perguruan tinggi seperti aplikasi Sistem Informasi Akademik (SIAKAD), Sistem Pendaftaran Mahasiswa Baru (SPMB), Sistem Informasi Kepegawaian (SIMPEG) dan Sistem Penjaminan Mutu internal (SPMI) dan sebagain ya.

Sekolah Tinggi Elektronika dan Komputer (STEKOM) Semarang merupakan Perguruan Tinggi Swasta di Semarang yang berdiri pada tahun 2002 sesuai dengan SK Mendiknas No. 235/D/O/2002. STEKOM yang memiliki beberapa kampus di beberapa lokasi yang berada di kota Semarang dan daerah yang berbatasan langsung dengan kota Semarang, yaitu di kota Semarang ada 3 lokasi kampus, di luar kota Semarang seperti di Ungaran, Sruwen, Ambarawa, Kaliwungu dan Kendal. Untuk memudahkan pengelolaan kampus-kampus STEKOM dikordinasikan dalam 3 Grup, yaitu Grup I untuk wilayah kampus bagian timur (Semarang Jl. Mjapahit 605 dan 304), bagian barat Grup II (Semarang Siliwangi, Kendal dan Weleri) serta bagian selatan grup III ( Ungaran, Sruwen dan Ambarawa). Pegawai STEKOM dibagi dalam 2 (dua) kelompok pegawai yaitu Tenaga Pendidik (Dosen) sejumlah 121 orang dan Tenaga Kependidikan (Tendik) sebanyak 59 orang yang meliputi : Pustakawan, Administrasi, Laboran, Teknisi serta Tenaga Penunjang seperti tenaga keamanan dan kebersihan. Setiap tahun dilakukan penilaian kinerja terhadap Tenaga Pendidik (dosen) dan Tenaga Kependidikan.

Sesuai ketentuan dari Kemenristekdikti setiap dosen diwajibkan untuk membuat laporan Sasaran Kerja Pegawai (SKP) pada setiap tahun yang mencakup penilaian karya Tridharma (Pendidikan, Penelitian dan Pengabdian Masyarakat serta Unsur penunjang) dan Penilaian Perilaku Kerja, dimana nilai SKP merupakan nilai gabungan antara Penilaian Kinerja Tridharma dosen (bobotnya 60\%) dan Penilaian Perilaku Kerja Pegawai (bobotnya 40\%). SKP ini akan digunakan dalam pengusulan pengajuan Jabatan Fungsional Dosen (JFD) atau usulan kenaikan JFD berikutnya, serta usulan kenaikan Gol./Ruang pangkat dosen (Inpassing pangkat) di LLDIKTI. Aspek penilaian perilaku kerja pegawai meliputi 6 (enam) unsur yang dinilai yaitu: Orientasi Pelayanan, Integritas, Komitmen, Disiplin, Kerjasama dan Kepemimpinan. Secara internal STEKOM menggunakan hasil Penilaian Perilaku Pegawai sebagai komponen utama dalam Penilaian Kinerja Pegawai STEKOM baik bagi Tenaga Pendidik (dosen) maupun Tenaga Kependidikan..

Penilaian Kinerja ini ditujukan untuk mengevaluasi kinerja pegawai selama satu tahun, yang hasilnya akan digunakan sebagai pertimbangan dalam menentukan kebijakan dalam penyesuaian gaji pegawai setiap tahun, mutasi atau promosi jabatan. Selama ini Penilaian Kinerja Pegawai Tenaga Pendidik dan Tenaga Kependidikan dilakukan oleh pimpinan dan kordinator cabang mengisi form penilain pada Ms. Excel, kemudian hasiln ya dikirimkan kepada bagian kepegawaian via e-mail. Bagian kepegawaian akan merekap data Ms. Ecxel yang masuk dan hasilnya akhir akan dilporkan kepada Ketua STEKOM. Proses penilaian kinerja pegawi dengan cara ini membutuhkan waktu relatif lama dan cenderung kurang efisien.

Berikut pada tabel 1 dibawah ini merupakan gambaran data jumlah tenaga pendidikan dan tenaga kependidikan serta tenaga penunjang disetiap grup kampus cabang STEKOM.

\section{SISTEM PENILAIAN KINERJA TENAGA PENDIDIK DAN TENAGA KEPENDIDIKAN BERBASIS WEB DI STEKOM SEMARANG}


Tabel 1: Tenaga Pendidik, Tenaga Kependidikan Dan Tenaga Penunjang.

\begin{tabular}{|c|c|c|c|c|c|c|c|c|}
\hline \multirow[b]{2}{*}{ No } & \multirow[b]{2}{*}{ Kampus Cabang } & \multirow{2}{*}{$\begin{array}{c}\text { Tenaga } \\
\text { Pendidik } \\
\\
\text { ฮ్ } \\
\text { ڤ̊ }\end{array}$} & \multicolumn{5}{|c|}{$\begin{array}{c}\text { Tenaga Kependidikan dan } \\
\text { Penunjang }\end{array}$} & \multirow[b]{2}{*}{$\begin{array}{c}\text { Total } \\
\text { Jumlah }\end{array}$} \\
\hline & & & 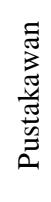 & 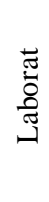 & 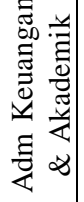 & 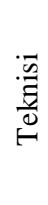 & 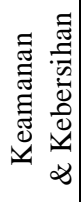 & \\
\hline 1 & Grup I & 42 & 3 & 3 & 8 & 2 & 5 & \\
\hline 2 & Grup II & 41 & 2 & 3 & 7 & 2 & 5 & \\
\hline 3 & Grup III & 38 & 2 & 3 & 7 & 2 & 4 & \\
\hline & Jumlah & 121 & 7 & 9 & 23 & 6 & 14 & 180 \\
\hline
\end{tabular}

Sumber Data : Bagian Kepegawaian STEKOM

Melihat permasalahan diatas serta dan guna mempersiapkan kebutuhan data tenaga kependidikan untuk pelaporan pada aplikasi Sistem Informasi Tenaga Kependidikan (Sistendik) Kemenristekdikti, maka penulis mengusulkan membangun Sistem Informasi Penilaian Kinerja Tenaga Pendidik dan Tenaga Kependidikan STEKOM yang berbasis web dimana di dalamnya sudah disediakan Biodata Pegawai, Riwayat Pendidikan, Riwayat Kepegawaian dan aplikasi Penilaian Kinerja Pegawai. Pertimbangan membuat sistem Informasi berbasis web adalah mengingat ban yaknya kampus cabang STEKOM yang berada di beberapa daerah yang cukup jauh, serta agar setiap koordinator cabang bisa mengakses sistem secara langsung dengan cepat guna menyampaikan informasi hasil penilaian pegawai dengan mudah dan cepat.

2. Perumusan Masalah

1. Bagaimana membuat desain Sistem Penilaian Kinerja untuk mempermudah proses dalam melakukan penilaian kinerj pegawai STEKOM yang valid ?

2. Apakah aplikasi Sistem Penilaian kinerja pegawai STEKOM yang dibangun bisa digunakan untuk mempermudah dan mempercepat proses penilaian kinerja pegawai di STEKOM?

\section{Landasan Teori}

a. Tenaga Pendidik dan Kependidikan

Menurut Pasal 39 Ayat 1 UU Nomor 20 Tahun 2003 tentang Sistem Pendidikan Nasional :

1) Tenaga Kependidikan bertugas melaksanakan administrasi, pengolahan, pengembangan, pengawasan, dan pelayanan teknis untuk menunjang proses pendidikan pada satuan pendidikan.

2) Tenaga Pendidik bertugas merencanakan dan melaksanakan proses pembelajaran, menilai hasil pembelajaran, melakukan pembimbingan dan pelatihan, serta melakukan penelitian dan pengabdian kepada masyarakat, terutama bagi pendidik pada perguruan tinggi

b. Kinerja dan Penilaian Kinerja

Kinerja dalam sebuah perusahaan merupakan jawaban atas berhasil atau gagalnya perusahaan dalam mencapai tujuan yang telah ditetapkan sebelumnya. Kinerja merupakan suatu kondisi dimana kita harus mengetahui dan dapat mengkonfirmasikan kepada pihak - pihak terkait sehingga dapat diketahui tingkatan keberhasilan sebuah instansi/perusahaan dalam pencapaian visi 
dan misi instansi/perusahaan, sehingga dapat diketahui ada seberapa dampak positif dan negatif dari suatu kebijakan operasional

Penilaian kinerja dapat diartikan sebagai upaya yang digunakan untuk mengadakan pengukuran atas kerja dari setiap karyawan dari sebuah instansi/perusahaan yang akan dikaitakan pada tingkat produktivitas dan efektifitas dari pekerjaan karyawan tersebut, sesuai tugas yang diberikan perusahaan kepada keyawan tersebut. Hasil dri penilaian kinerja akan digunakan sebagai bahan pertimbangan untuk peningkatan produktifiatas dan efektivitas perusahaan (Rismawati, Mattalata 2018).

c. Tenaga Pendidik dan Kependidikan

Menurut Pasal 39 Ayat 1 UU Nomor 20 Tahun 2003 tentang Sistem Pendidikan Nasional :

3) Tenaga Kependidikan bertugas melaksanakan administrasi, pengolahan, pengembangan, pengawasan, dan pelayanan teknis untuk menunjang proses pendidikan pada satuan pendidikan.

4) Tenaga Pendidik bertugas merencanakan dan melaksanakan proses pembelajaran, menilai hasil pembelajaran, melakukan pembimbingan dan pelatihan, serta melakukan penelitian dan pengabdian kepada masyarakat, terutama bagi pendidik pada perguruan tinggi

d. Rubrik Penilaian Perilaku Kerja

Tabel 2 : Rubrik Kriteria Penilaian Perilaku Kerja

\begin{tabular}{|c|c|c|c|c|}
\hline \multirow{2}{*}{ No. } & \multirow{2}{*}{$\begin{array}{l}\text { Aspek } \\
\text { Yang } \\
\text { Dinilai }\end{array}$} & \multirow{2}{*}{ Kreteria } & \multicolumn{2}{|c|}{ Nilai } \\
\hline & & & Angka & Sebutan \\
\hline \multirow{5}{*}{1} & \multirow{5}{*}{$\begin{array}{l}\text { Orientasi } \\
\text { Pelayanan }\end{array}$} & $\begin{array}{l}\text { Selalu dapat menyelesaikan tugas pelayanan sebaik } \\
\text { - baiknya dengan sikap sopan dan sangat } \\
\text { memuaskan baik pelayanan internal maupun } \\
\text { eksternal organisasi }\end{array}$ & $91-100$ & Sangat Baik \\
\hline & & $\begin{array}{l}\text { Pada umumnya dapat menyelesaikan tugas } \\
\text { pelayanan sebaik - baiknya dengan sikap sopan dan } \\
\text { sangat memuaskan baik pelayanan internal maupun } \\
\text { eksternal organisasi }\end{array}$ & $76-90$ & Baik \\
\hline & & $\begin{array}{l}\text { Adakalanya dapat menyelesaikan tugas pelayanan } \\
\text { sebaik - baiknya dengan sikap sopan dan sangat } \\
\text { memuaskan baik pelayanan internal maupun } \\
\text { eksternal organisasi }\end{array}$ & $61-75$ & Kurang \\
\hline & & $\begin{array}{l}\text { Kurang dapat menyelesaikan tugas pelayanan } \\
\text { sebaik - baiknya dengan sikap sopan dan sangat } \\
\text { memuaskan baik pelayanan internal maupun } \\
\text { eksternal organisasi }\end{array}$ & $51-60$ & Cukup \\
\hline & & $\begin{array}{l}\text { Tidak pernah dapat menyelesaikan tugas pelayanan } \\
\text { sebaik - baiknya dengan sikap sopan dan sangat } \\
\text { memuaskan baik pelayanan internal maupun } \\
\text { eksternal organisasi }\end{array}$ & $<50$ & Buruk \\
\hline \multirow{3}{*}{2} & \multirow{3}{*}{ Integritas } & $\begin{array}{l}\text { Selalu melaksanakan tugas bersifat jujur, ikhlas, } \\
\text { dan tidak pernah menyalagunakan wewenang serta } \\
\text { berani menaggung risiko dari tindakan yang } \\
\text { dilakukannya. }\end{array}$ & $91-100$ & Sangat Baik \\
\hline & & $\begin{array}{l}\text { Pada umunya dalam melaksanakan tugas bersifat } \\
\text { jujur, ikhlas, dan tidak pernah menyalagunakan } \\
\text { wewenang serta berani menaggung risiko dari } \\
\text { tindakan yang dilakukannya. }\end{array}$ & $76-90$ & Baik \\
\hline & & $\begin{array}{l}\text { Adakalanya dalam melaksanakan tugas bersifat } \\
\text { jujur, ikhlas, dan tidak pernah menyalagunakan }\end{array}$ & $61-75$ & Kurang \\
\hline
\end{tabular}




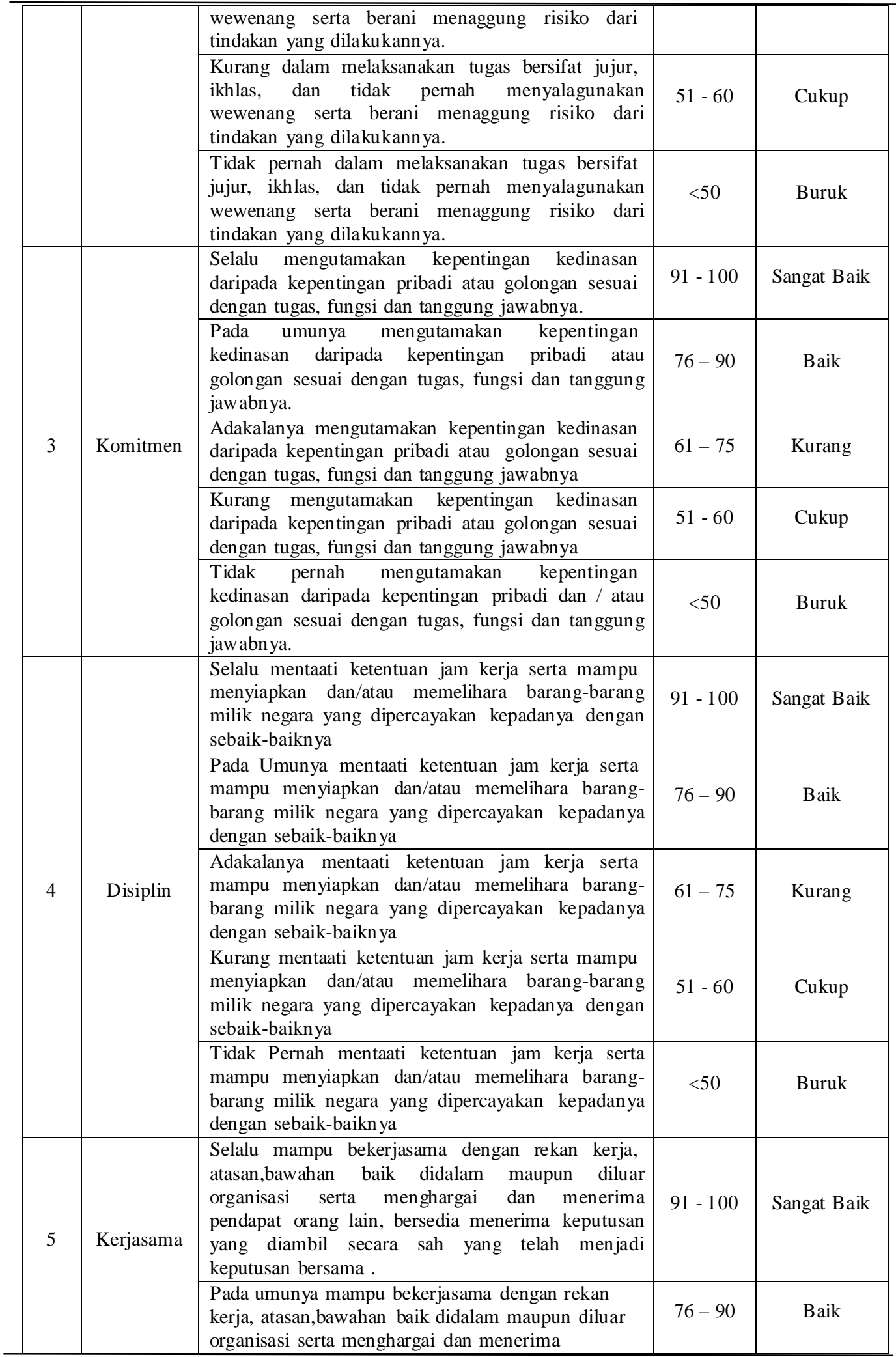

JURNAL ILMIAH ELEKTRONIKA DAN KOMPUTER Vol. 13, No. 1, Juli 2020 : 18 - 33 


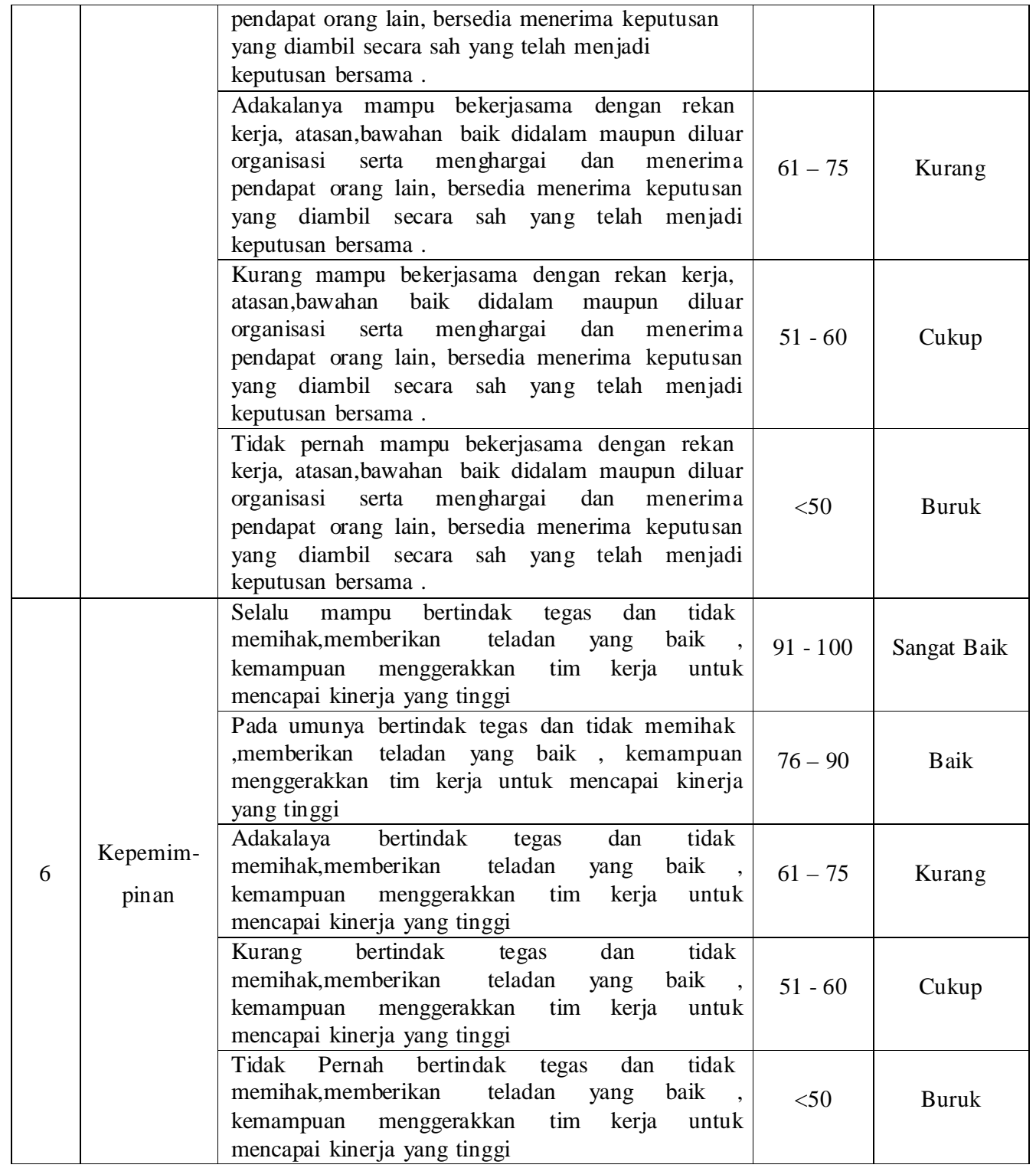

e. Website

Bekti (2015) menjelaskan website merupakan situs yang dapat diartikan sebagai kumpulan dari halaman yang digunakan untuk menampilkan sebuah informasi dalam bentuk multimedia yang berupa : tulisan, foto, gambar animasi dan video, suara dan musik, atau gabungan dari semua tersebut baik yang bersifat diam maupun bersifat dinamis yang digunakan untuk membentuk satu kolaborasi tampilan yang saling berkaitan, dimana masing - masing telah terhubung dalam berbagai halaman.

f. HTML (Hypertext Markup Language)

HTML merupakan singkatan dari "Hypertext Markup Language", disebut dengan Hypertext karena di dalam suatu script HTML, dimana diharuskan untuk membuat sebuah teks menjadi suatu link yang dapat digunakan untuk berpindah halaman yang satu ke halaman lainnya dengan meng-klik teks tersebut. Teks yang diberi link inilah yang disebut dengan Hypertext di karenakan dalam sebuah website adalah dokumen yang terdapat banyaknya link untuk menghubungkan satu dokumen dengan yang lainnya (Jubilee Enterprise, 2018).

\section{SISTEM PENILAIAN KINERJA TENAGA PENDIDIK DAN TENAGA KEPENDIDIKAN BERBASIS WEB DI STEKOM SEMARANG}


g. Data base MySQL

MySQL merupakan sebuah aplikasi DBMS yang sering digunakan oleh para pengembang aplikasi pemograman website. MySQL merupakan aplikasi Open Source dan selalu melakukan pembaruan, dimana banyak forum di internet yang yang bisa digunakan untuk mendiskusikan jika mengalami suatu kendala. MySQL aplikasi DBMS yang sering di gabungkan dengan web server, seperti WAMP Server, XAMPP dan sebagainya, sehingga proses instalasinya akan lebih mudah (Priyanto, Hidayatullah dkk, 2015).

Supono dan Pratama (2018) mengatakan MySQL merupakan sebuah sistem manajemen database SQL yang paling populer untuk saat ini, MySQL merupakan database yang bersifat Open Source. MySQL database didukung oleh berberapa fitur seperti multiuser, multithreded dan SQL database manajemen sistem (DBMS)

h. Notepad ++

Menurut Madcoms (2016) Notepad++ merupakan perangkat lunak aplikasi editor teks yang berguna dalam pembuatan program aplikasi sehingga memudahkan bagi pengembang aplikasi. Notepad++ membutuhkan sebuah komponen Scintilla yang digunakan untuk menampilkan teks dan kode program yang telah dibuat di Notepad++, Scintilla merupakan sumber untuk menampilkan berbagai bahasa pemograman yang dijalankan pada sistem operasi windows.

\section{Metodologi}

a. Model Pengembangan Sistem

Dalam melakukan penelitian ini digunakan metode pengembangan sistem dengan pendekatan metode R \& D (Research and Development) oleh Brog \& Gall (1987), yang merupakan suatu metode penelitian yang sering digunakan untuk mengembangkan produk yang akan diuji keefektifannya. Pada Penelitian hanyai digunakan 6 tahapan dari 10 tahapan yang dikemukakan oleh Borg \& Gall, seperti di bawah ini :

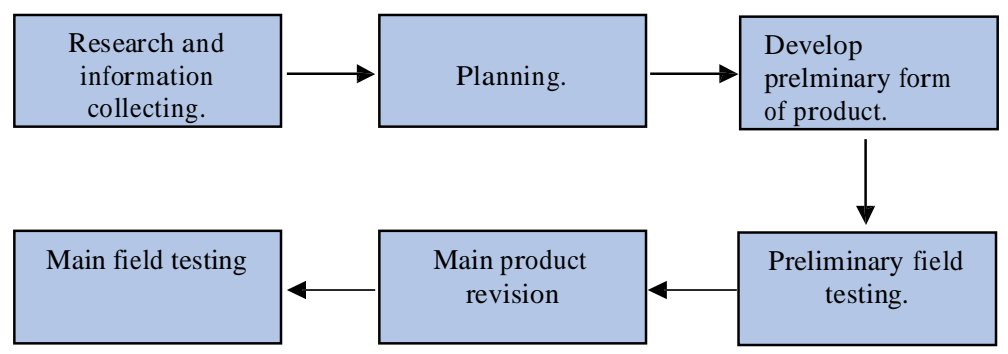

Gambar 1. Tahapan model Pengembangan R\&D (Borg \& Gall)

b. Prosedur Pengembangan

Prosedur pengembangan Produk sesuai tahapan dalam metode pengembangan Research and Development (R\&D) dari Borg dan Gall, dimulai dari tahapan desain sistem yang dilanjutkan dengan validasi desain oleh pakar sampai dinyatakan desainnya valid. Setelah itu dilanjutkan pembuatan source code menjadi aplikasi yang bisa bekerja yang sudah bisa diuji oleh calon user. Calon user akan menguji produk aplikasi sampai dinyatakan sudah bisa bekerja memenuhi kebutuhan user. Tahapan prosedur pengembangan dapat dilihat pada gambar 2 dibawah ini.

JURNAL ILMIAH ELEKTRONIKA DAN KOMPUTER Vol. 13, No. 1, Juli $2020: 18$ - 33 
141141141

JURNAL ILMIAH ELEKTRONIKA DAN KOMPUTER p-ISSN: 1907-0012 e-ISSN : 2714-5417

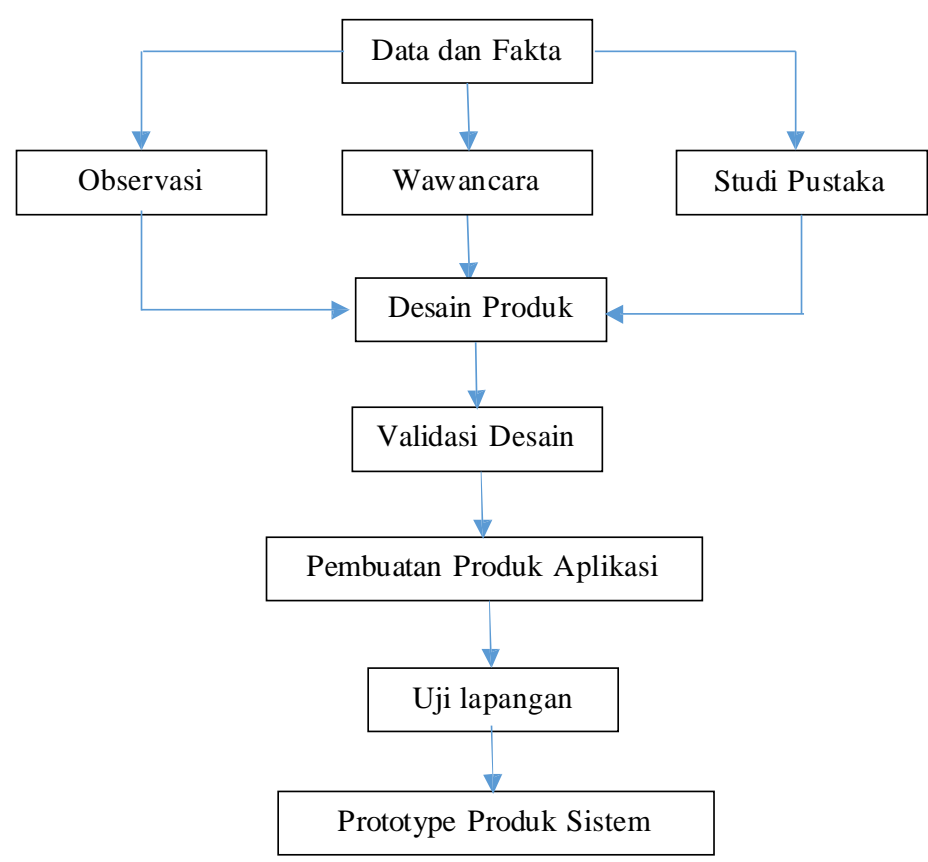

Gambar 2. Prosedur Pengembangan Sistem

5. Desain Sistem

a. Desain Arsitektural Sistem

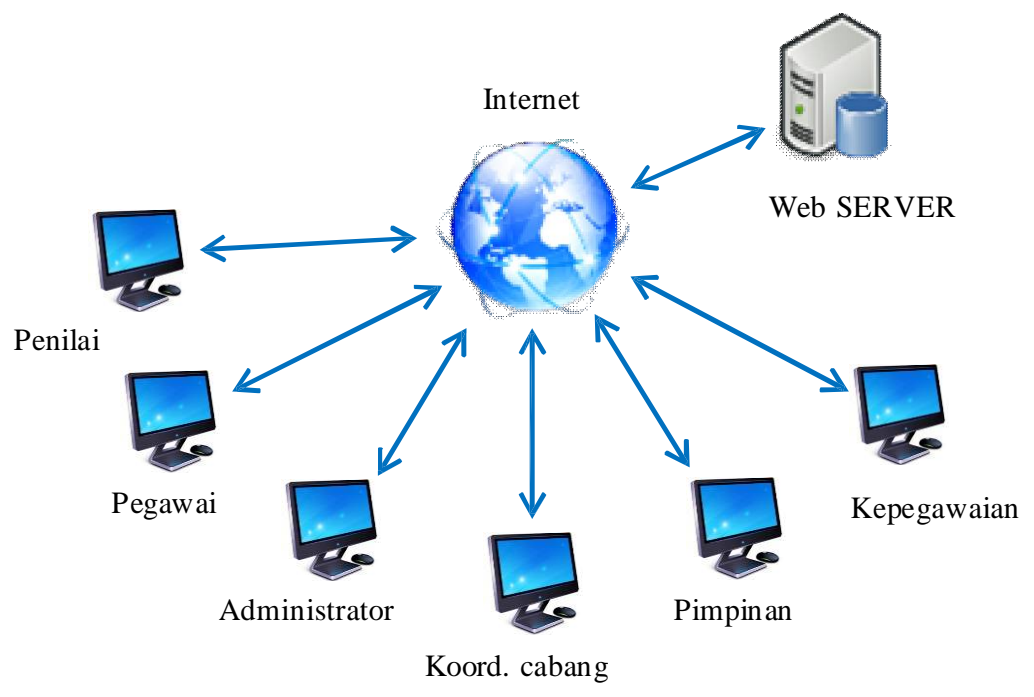

Gambar 3. Desain Arsitektural Sistem 
b. Desain Use Case diagram

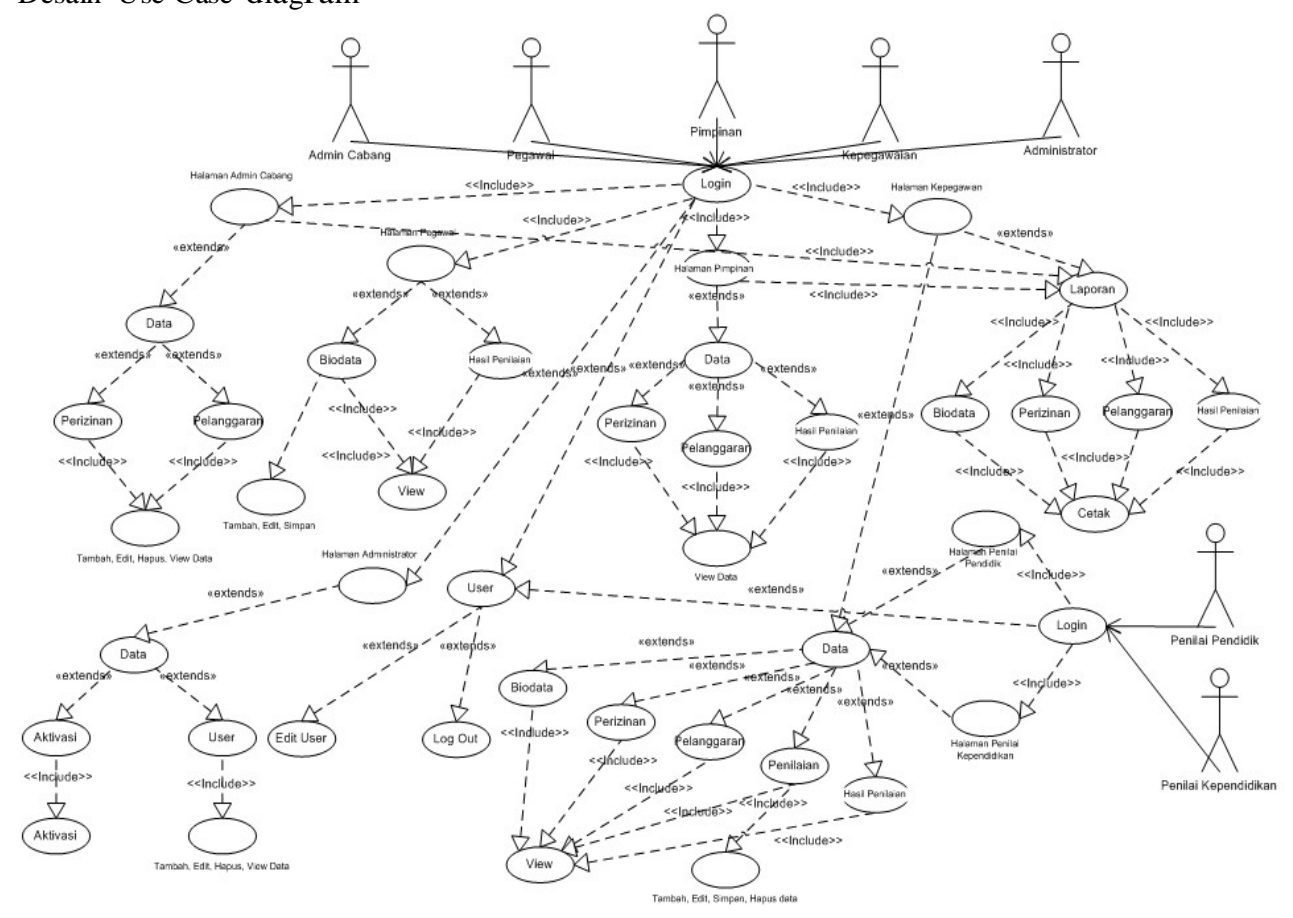

Gambar 4. Use Case Diagram

c. Desain Class Diagram

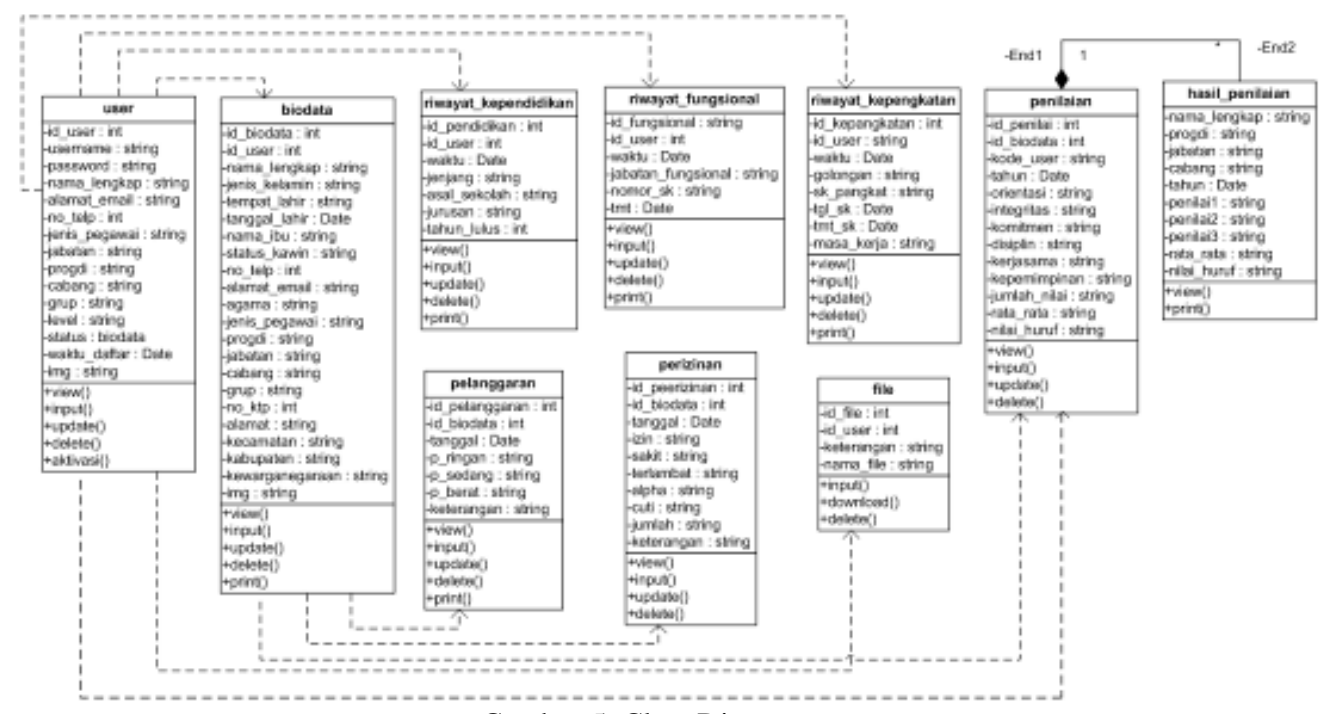

Gambar 5. Class Diagram 
d. Desain Database

1) Tabel tb_user

Tabel 3. Struktur Tabel User

\begin{tabular}{|c|l|c|c|}
\hline NO & \multicolumn{1}{|c|}{ Nama Field } & Type & Length/Values \\
\hline 1 & id_user & int & 5 \\
\hline 2 & username & varchar & 100 \\
\hline 3 & password & varchar & 150 \\
\hline 4 & nama_lengkap & varchar & 150 \\
\hline 5 & alamat_email & varchar & 30 \\
\hline 6 & no_telp & varchar & 15 \\
\hline 7 & Jenis_jabatan & varchar & 30 \\
\hline 8 & Jabatan & varchar & 20 \\
\hline 19 & Progdi & varchar & 20 \\
\hline 10 & Cabang & varchar & 20 \\
\hline 11 & Grup & varchar & 10 \\
\hline 12 & Level & varchar & 20 \\
\hline 13 & Status & enum & $\left(' Y^{\prime}, \mathrm{N}^{\prime}\right.$ ') \\
\hline 14 & waktu_daftar & datetime & \\
\hline 15 & Img & varchar & 300 \\
\hline
\end{tabular}

2) Tabel tb_biodata

Tabel 4. Struktur tabel Biodata

\begin{tabular}{|c|l|c|c|}
\hline NO & \multicolumn{1}{|c|}{ Nama Field } & Type & Length/Values \\
\hline 1 & id_biodata & int & 5 \\
\hline 2 & id_user & int & 10 \\
\hline 3 & nama_lengkap & varchar & 50 \\
\hline 4 & jenis_kelamin & varchar & 20 \\
\hline 5 & tempat_lahir & varchar & 20 \\
\hline 6 & tanggal_lahir & date & \\
\hline 7 & nama_ibu & varchar & 30 \\
\hline 8 & status-kawin & varchar & 20 \\
\hline 9 & no_telp & varchar & 20 \\
\hline 10 & alamat_email & varchar & 30 \\
\hline 11 & agama & varchar & 20 \\
\hline 12 & jenis_pegawai & varchar & 20 \\
\hline 13 & progdi & varchar & 20 \\
\hline 14 & jabatan & varchar & 15 \\
\hline 15 & cabang & varchar & 15 \\
\hline 16 & grup & varchar & 5 \\
\hline 17 & no_ktp & varchar & 20 \\
\hline 18 & alamat & varchar & 150 \\
\hline 19 & kecamatan & varchar & 30 \\
\hline 20 & kabupaten & varchar & 30 \\
\hline 21 & kewarganegaraan & varchar & 20 \\
\hline 22 & img & varchar & 150 \\
\hline
\end{tabular}


3) Tabel tb_penilaian

Tabel 5. Struktur tabel penelitian kinerja

\begin{tabular}{|c|l|c|c|}
\hline NO & \multicolumn{1}{|c|}{ Nama Field } & Type & Length/Values \\
\hline 1 & id_penilai & Int & 5 \\
\hline 2 & id_user & int & 10 \\
\hline 3 & id_biodata & int & 10 \\
\hline 4 & Tahun & year & 4 \\
\hline 5 & Orientasi & varchar & 5 \\
\hline 6 & Integritas & varchar & 5 \\
\hline 7 & Komitmen & varchar & 5 \\
\hline 8 & Disiplin & varchar & 5 \\
\hline 9 & Kerjasama & varchar & 5 \\
\hline 10 & kepemimpinan & varchar & 5 \\
\hline 11 & jumlah_nilai & varchar & 5 \\
\hline
\end{tabular}

e. Desain User Interface

1) From Login

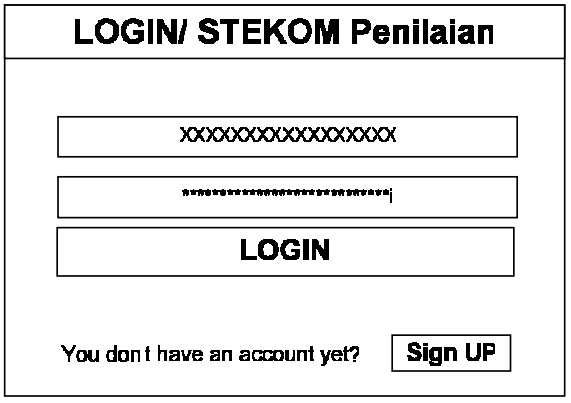

Gambar 6. Desain Form Login

2) From Input Pendaftaran Akun

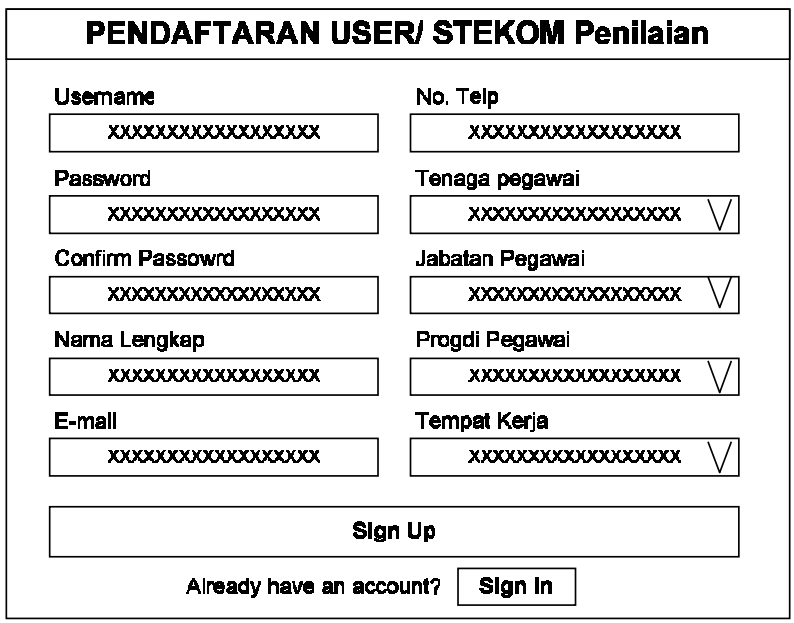

Gambar 7. Desain Form Pendaftaran.

JURNAL ILMIAH ELEKTRONIKA DAN KOMPUTER Vol. 13, No. 1, Juli 2020 : 18 - 33 
3) Form Penilai

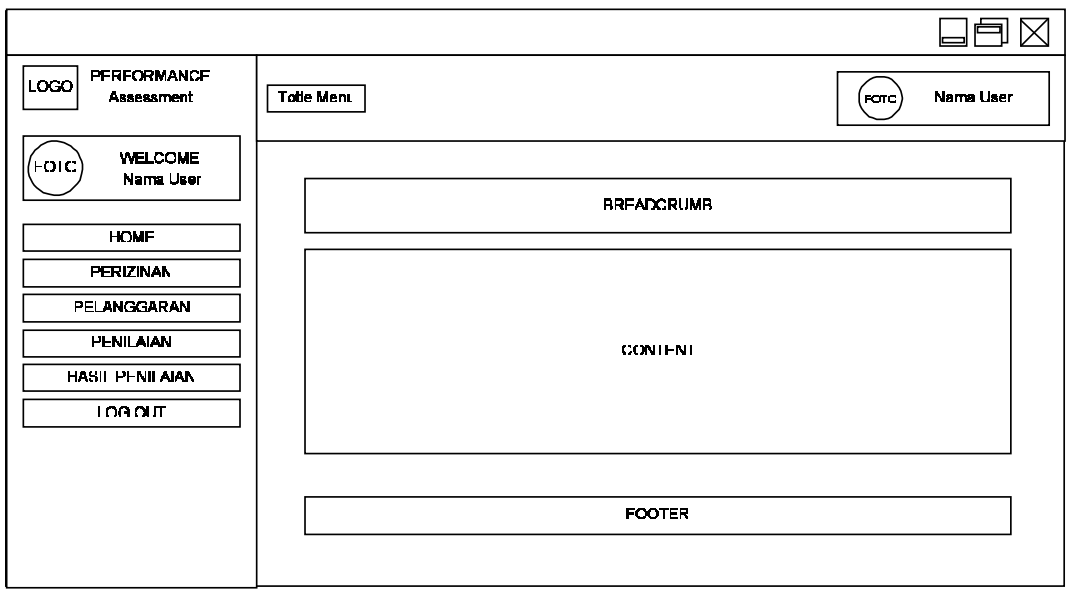

Gambar 8. Desain Form Penilai

4) From Input Penilaian Pegawai

\begin{tabular}{|c|c|c|c|c|}
\hline \multicolumn{5}{|l|}{ Input Penilaian } \\
\hline \multicolumn{3}{|l|}{ BIODATA } & \multicolumn{2}{|l|}{ PENILAIAA } \\
\hline Nama Pegawaĩ & $: x \times x x x x x x$ & $\nabla$ & Nama Penilai & $: \quad x \times 0 x x \times x$ \\
\hline Progdi & $x>0000 x x$ & & Tahun Penilaiar & : 999999995 \\
\hline Jabatan & : $x x x x y x x$ & & Orientasi Pelayanan * & : 999999999 \\
\hline \multirow[t]{11}{*}{ Tempat Keria } & $: x x x x x x x x$ & & Integrttas* & $: 90999090 \varepsilon$ \\
\hline & & & Komitmen* & 999999996 \\
\hline & & & Disiplin" & 999999998 \\
\hline & & & Kerjasama & $89980909 \varepsilon$ \\
\hline & & & Keterangan* & : 999999998 \\
\hline & & & Kepemimpinan' & : 999999998 \\
\hline & & & Jumlah N|lal & : 99999999 \\
\hline & & & Nilai Rata - Rata & : 999999995 \\
\hline & & & Nilai Huruf & $: \quad x x x x x x x$ \\
\hline & & & \multicolumn{2}{|c|}{ Catrlan : Data Yang Bertanda (") Wallb dl |sl! } \\
\hline & & & \begin{tabular}{|l|l} 
SIMPAN RESET \\
\end{tabular} & CANCEL \\
\hline
\end{tabular}

Gambar 9. Desain Form Input Penilaian Pegawai

5) Form Laporan Cetak Hasil Penilaian Pegawai

\begin{tabular}{|c|c|c|c|c|c|c|c|c|c|c|}
\hline \multicolumn{2}{|c|}{$\begin{array}{l}\text { LOGO } \\
\text { STEKOM }\end{array}$} & \multicolumn{7}{|c|}{$\begin{array}{l}\text { STEKOM } \\
\text { SEKOLAH TINOO ELEKTROHIKA \& KOMPUTER } \\
\text { dIl. Majapahit No.605 Telp 6710144 \& } 304 \text { telp 67172D1-0z Semaranç }\end{array}$} & & \\
\hline \multicolumn{11}{|c|}{ DATA HASIL PENILAIAN PEGAWAI } \\
\hline \multicolumn{8}{|c|}{ Pegawai } & Diçetak & : Hari & $00-00-0000$ \\
\hline Nc & Nama Lengkap & Progd & Jabatar & Tempat Kerla & Tahur & Penllal|' & Penllal2 & \begin{tabular}{|l|} 
Penllala \\
\end{tabular} & Rata-Ratg & Keterangar \\
\hline
\end{tabular}

Gambar 10. Desain Laporan Cetak Hasil Penilaian 
6) Form Tabel Cetak Hasil Penilain Pegawai

\begin{tabular}{|c|c|c|c|c|c|c|c|c|c|c|c|}
\hline \multicolumn{12}{|c|}{ Cetak Hasil Penilaian Pegawa } \\
\hline \multicolumn{2}{|c|}{ SelectPegawa $\bigvee$} & \multicolumn{3}{|c|}{ Select Tpt Kerja $\nabla \backslash$ TahurV } & \multirow[t]{2}{*}{ View } & \multicolumn{2}{|c|}{ Cetak } & \multirow{2}{*}{\multicolumn{2}{|c|}{ Search }} & \multirow{2}{*}{\multicolumn{2}{|c|}{$\mathbf{x 0 0 x x}$}} \\
\hline \multicolumn{2}{|c|}{ Show } & \multicolumn{3}{|c|}{ entries } & & & & & & & \\
\hline No & Nama Lengkap & Progdi & Jabatar & Tempat Kerja & Tahur & $\mathbf{P}^{*}$ & P2 & P3 & Rata - Rata & Keter & angan \\
\hline 1 & & & & & & & & & & & \\
\hline 2 & & & & & & & & & & & \\
\hline 3 & & & & & & & & & & & \\
\hline 4 & & & & & & & & & & & \\
\hline 5 & & & & & & & & & & & \\
\hline & Showing 1 to 1 & f 1 ent & & & & & & & Prevlo & 1 & Next \\
\hline
\end{tabular}

Gambar 11. Desain Cetak Hasil Penilaian pegawai

7) Instrumen Penelitian

a) Bentuk Instrumen Penelitian

Instrumen penelitian dalam bentuk angket digunakan untuk pengujian desain oleh dosen yang kompeten (pakar) dan Pengujian Produk dilakukan oleh calon user. Instrumen penelitian masing-masing berisi 10 pertanyaan yang akan diberikan penilaian oleh pakar uuntuk Pengujian desain, dan penilian produk oleh masing-masing calon user. Pakar dan calon user akan memberikan penilaian dalam range nilai 1 sampai 4 untuk setiap aspek indikator, dengan cara mencentrang salah satu pada kolom nilai (angka 1,2,3 atau 4), dimana : nilai 1 = belum/kurang, $2=$ ragu-ragu antara ya dan tidak, $3=$ cukup baik, dan 4 $=$ baik/baik Sekali.

b) Score Penilaian

Hasil penilaian setiap aspek pada instrumen penelitian akan dijumlahkan dan nilai akhirnya akan diukur menggunakan tabel skor di bawah ini

Tabel 6. Skor Penlaian

\begin{tabular}{|c|c|}
\hline SKOR & NILAI \\
\hline $1 \leq \mathrm{n} \leq 10$ & Tidak Baik \\
\hline $11 \leq \mathrm{n} \leq 20$ & Cukup \\
\hline $21 \leq \mathrm{n} \leq 30$ & Baik \\
\hline $31 \leq \mathrm{n} \leq 40$ & Sangat Baik \\
\hline
\end{tabular}

c) Kesimpulan hasil penilaian

Dari skor hasil penilaian dapat diambil kesimpulan sesuai dengan tabel 7 dibawah ini :

Tabel 7. Kesimpulan hasil penlaian

\begin{tabular}{|c|l|}
\hline No & \multicolumn{1}{|c|}{ KESIMPULAN } \\
\hline 1 & Tidak dapat digunakan dan harus diganti \\
\hline 2 & Sudah dapat digunakan tapi dengan banyak revisi \\
\hline 3 & Sudah dapat digunakan tapi dengan sedikit revisi \\
\hline 4 & Sudah dapat digunakan tanpa revisi \\
\hline
\end{tabular}

JURNAL ILMIAH ELEKTRONIKA DAN KOMPUTER Vol. 13, No. 1, Juli 2020 : 18 - 33 
147147147

JURNAL ILMIAH ELEKTRONIKA DAN KOMPUTER p-ISSN: 1907-0012 e-ISSN : 2714-5417 $\square$

6. Hasil dan Pembahasan

a. Hasil Pengembangan

1) Tampilan Form Login

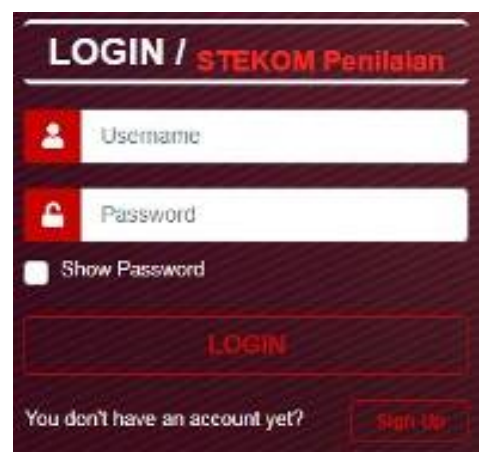

Gambar 12. Tampilan Form Login

2) Tampilan menu utama
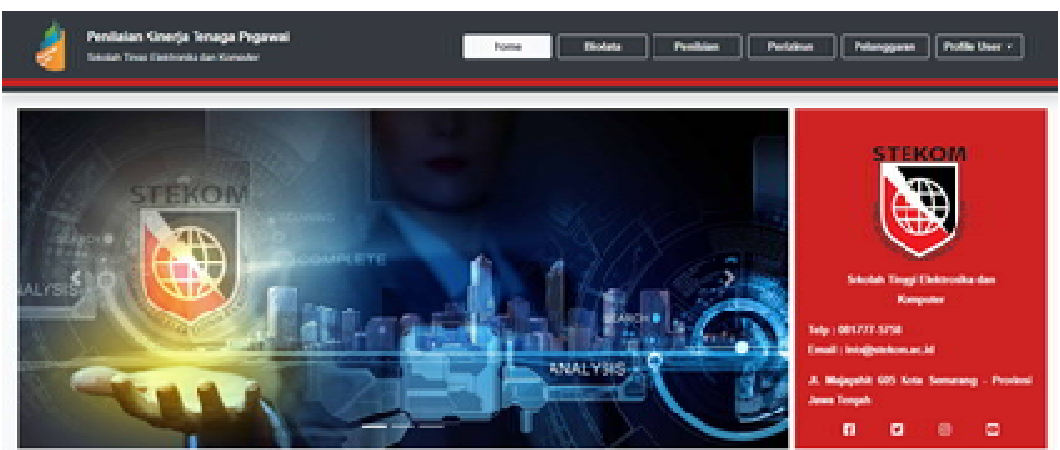

011

0

18

04

Gambar 13. Tampilan menu utama

3. Tampilan Form Pendaftaran User Pegawai

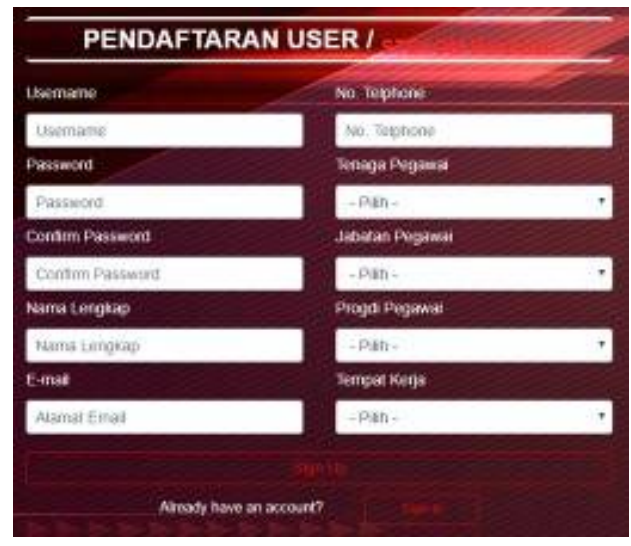

Gambar 14 Tampilan Form Pendaftaran User Pegawa

4) Tampilan menu Kepegawaian

SISTEM PENILAIAN KINERJA TENAGA PENDIDIK DAN TENAGA KEPENDIDIKAN BERBASIS WEB DI STEKOM SEMARANG 


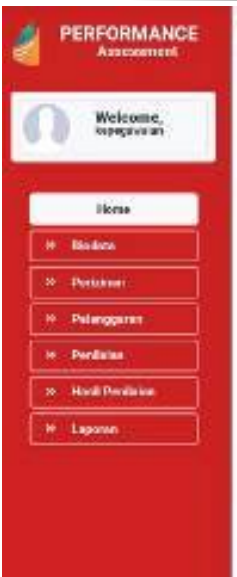

\section{ETopile He:u}

A Homepage Kepegawaian

Deshbeand i Hene

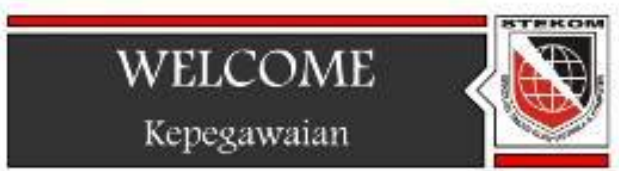

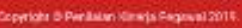

Gambar 15. Tampilan Menu Kepegawaian

5) Tampilan menu Input dataPegawai

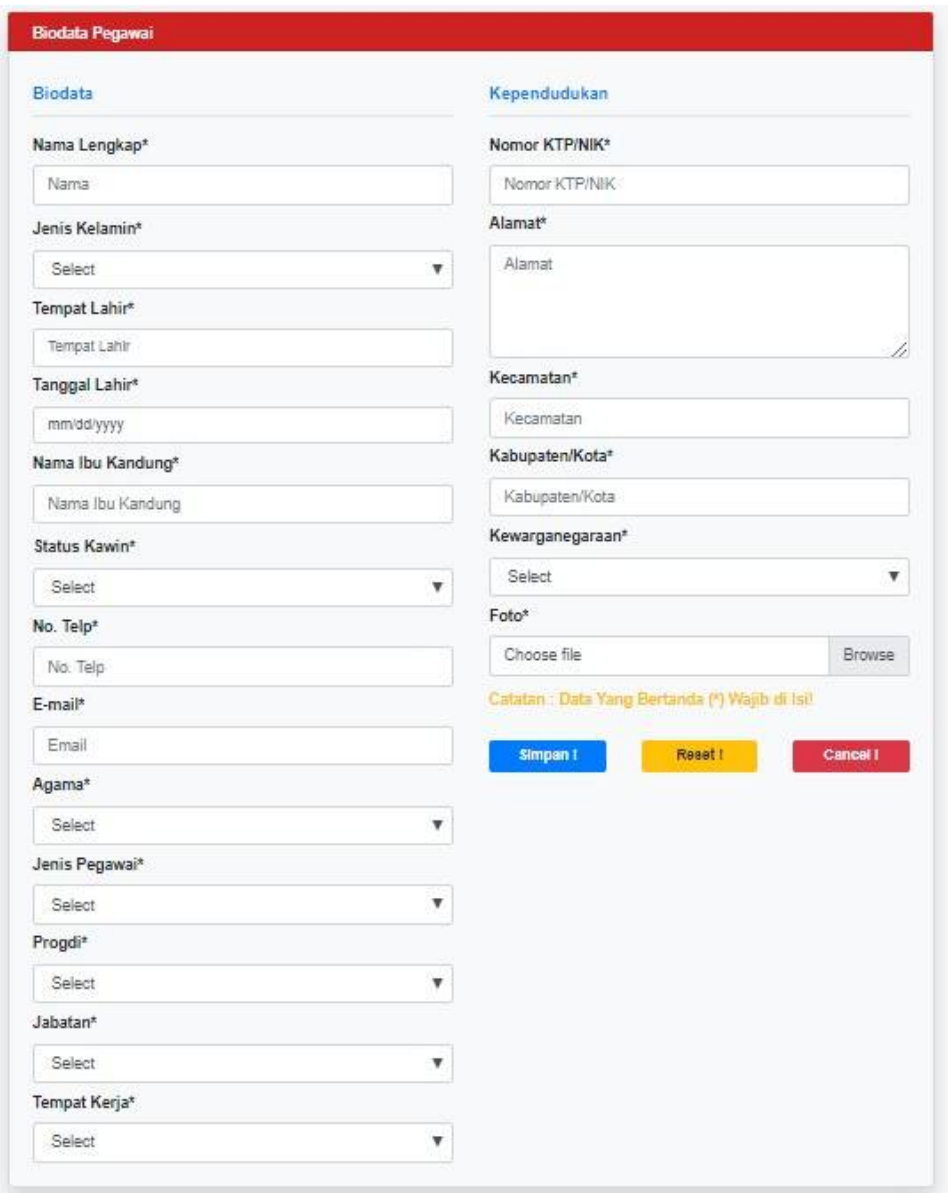

Gambar 16. Tampilan menu input data pegawai

JURNAL ILMIAH ELEKTRONIKA DAN KOMPUTER Vol. 13, No. 1, Juli 2020 : 18 - 33 
149149149

JURNAL ILMIAH ELEKTRONIKA DAN KOMPUTER p-ISSN: 1907-0012 e-ISSN : 2714-5417

6) Tampilan input data penilaian pegawai

\begin{tabular}{|c|c|c|c|}
\hline \multicolumn{2}{|l|}{ Biodata } & \multicolumn{2}{|l|}{ Penilaian } \\
\hline Nama Pegmeni & owhet & Namn Penilar & 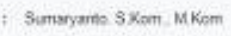 \\
\hline Progdi & 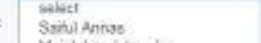 & Tahun Pesilisian & : 2020 \\
\hline Jatbatien & 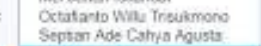 & Oriemtasi Pelagonen" & $: 0$ \\
\hline \multirow[t]{10}{*}{ Tempor Kesjo } & 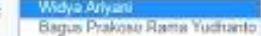 & imitegitios" & 0 \\
\hline & 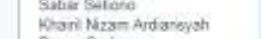 & Komitures" & 0 \\
\hline & 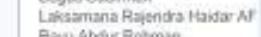 & Displie" & : \\
\hline & Begus Instranan Wiaksono & Keerjassma" & ; \\
\hline & & Kopamimpinain" & in \\
\hline & & Jumtah Nilari & : - \\
\hline & & Nisi Rma-Ross & ; \\
\hline & & Nibillturut & $t=$ \\
\hline & & 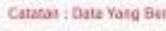 & 17) waib a ast \\
\hline & & Smagan: Rasect: & Concil 1 \\
\hline
\end{tabular}

Gambar 17. Tampilan Input data penilaian pegawai

7) Tampilan hasil Penilaian Pegawai

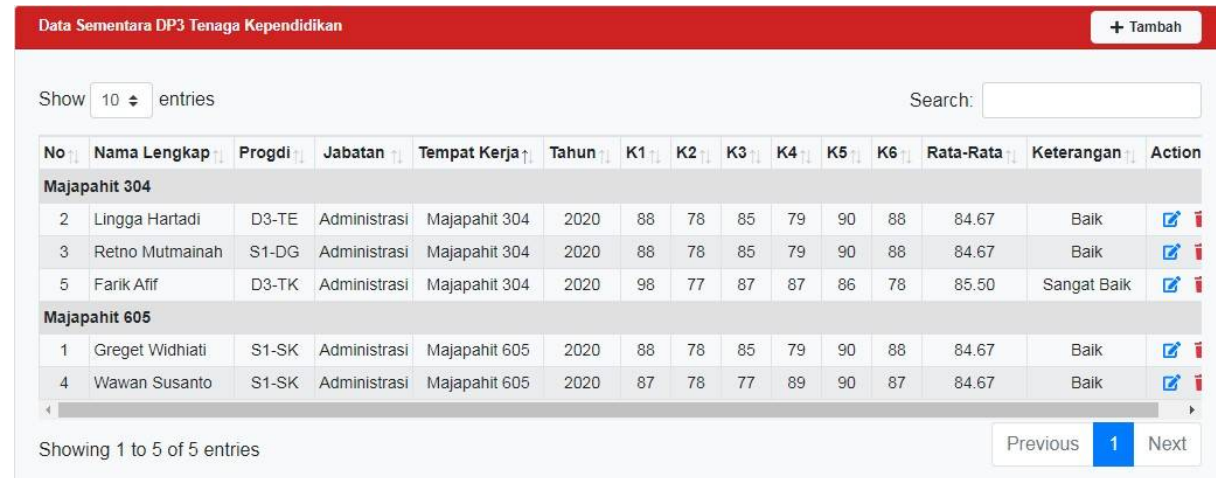

Gambar 18. Tampilan hasil penilaian pegawai

8) Tampilan hasilpenilaian pegawai oleh semua tim penilai

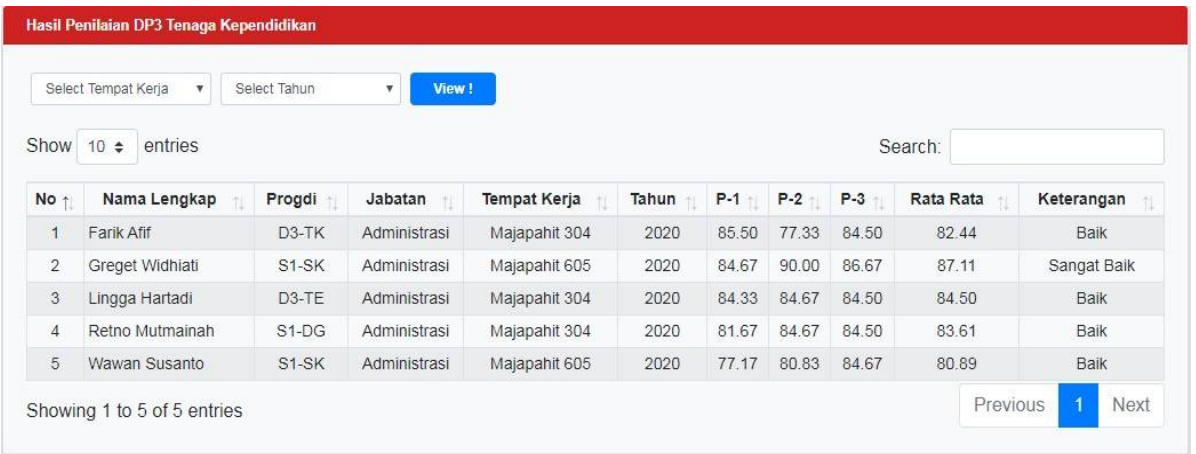

Gambar 19. Tampilan hasil penilaian pegawai oleh semua tim penilai

SISTEM PENILAIAN KINERJA TENAGA PENDIDIK DAN TENAGA KEPENDIDIKAN BERBASIS WEB DI STEKOM SEMARANG 
b. Hasil Pengujian

Pengujian Sistem dilakukan melalui 2 tahapan yaitu Pengujian Desain oeh Pakar dan Pengujian Produk oleh calon user.

1) Pengujian Desain

Dilakuan pengujian untuk aspek desain meliputi : arsitektur sistem, flowchart, use case diagram, sequence diagram, activity diagram, class diagram, database, user interface.

Tabel 8. Skor Hasil Penilaian Desain oleh Pakar

\begin{tabular}{|c|c|}
\hline $\begin{array}{c}\text { Nomor Pertanyaan } \\
\text { (Aspek Desain) }\end{array}$ & Nilai Skor \\
\hline 1 & 4 \\
\hline 2 & 4 \\
\hline 3 & 4 \\
\hline 4 & 4 \\
\hline 5 & 4 \\
\hline 6 & 4 \\
\hline 7 & 4 \\
\hline 8 & 4 \\
\hline 9 & 4 \\
\hline 10 & 4 \\
\hline Total Skor & 39 \\
\hline
\end{tabular}

Dari hasil pengujian desain disapat Nilai skor 39, sesuai tabel 6 (Penilaian skor) masuk dalam range tabel skor $31 \leq \mathrm{n} \leq 40$ (sangat baik) dan sesuai tabel 7 (Kesimpulan) : Desain dapat digunakan tanpa revisi (valid).

2) Pengujian Produk

Pengujian Produk meliputi aspek operasional, pemenuhan kebutuhan, dan pencapaian tujuan.

Tabel 9. Skor Pengujian Produk oleh calon User

\begin{tabular}{|c|c|c|c|c|c|c|c|}
\hline $\begin{array}{c}\text { No Pertanyaan (Aspek } \\
\text { Penggunaan) }\end{array}$ & $\begin{array}{c}\text { User } \\
1\end{array}$ & $\begin{array}{c}\text { User } \\
2\end{array}$ & $\begin{array}{c}\text { User } \\
3\end{array}$ & $\begin{array}{c}\text { User } \\
4\end{array}$ & $\begin{array}{c}\text { User } \\
5\end{array}$ & $\begin{array}{c}\text { User } \\
6\end{array}$ & $\begin{array}{c}\text { User } \\
7\end{array}$ \\
\hline 1 & 4 & 4 & 4 & 4 & 3 & 3 & 4 \\
\hline 2 & 4 & 4 & 4 & 4 & 4 & 4 & 4 \\
\hline 3 & 4 & 4 & 4 & 3 & 4 & 4 & 4 \\
\hline 4 & 4 & 4 & 4 & 4 & 3 & 4 & 4 \\
\hline 5 & 4 & 4 & 4 & 4 & 4 & 4 & 4 \\
\hline 6 & 4 & 4 & 3 & 3 & 3 & 4 & 4 \\
\hline 7 & 3 & 3 & 4 & 4 & 4 & 4 & 4 \\
\hline 8 & 4 & 4 & 4 & 4 & 4 & 4 & 4 \\
\hline 9 & 4 & 4 & 4 & 4 & 3 & 4 & 4 \\
\hline 10 & 4 & 4 & 4 & 4 & 3 & 4 & 4 \\
\hline Total Skor & 39 & 39 & 39 & 38 & 35 & 39 & 40 \\
\hline
\end{tabular}

Skor yang diperoleh dari penilaian calon user yaitu :

Skor rata-rata $=\frac{39+39+39+38+35+39+40}{7}=30$ (Sangat Baik)

Dari hasil pengujian yang tunjukan pada tabel 9 diatas, rata-rata skor pengujian oleh 7 oramg calon user diperoleh nilai rata-rata 38. Berdasarkan tabel 6 diatas nilai skor tersebuat masuk kedalam range nilai $31 \leq \mathrm{n} \leq 40$ yang berarti sangat baik. Untuk kesimpulannya mengikuti tabel 7 , yaitu bahwa aplikasi yang dikembangan dapat digunakan tanpa revisi.

JURNAL ILMIAH ELEKTRONIKA DAN KOMPUTER Vol. 13, No. 1, Juli 2020 : 18 - 33 
7. Kesimpulan

Berdasarkan hasil penelitian dan pengembangan yang telah diuraikan diatas, maka dapat disimpulkan bahwa aplikasi Sistem Penilaian Kinerja Pegawai yang dikembangkan telah dapat :

1. Mendokumentasikan biodata pegawai dengan baik pada database.

2. Penilaian kinerja setiap pegawai sudah bisa dilakukan secara online sehingga bisa dilakukan lebih cepat dan lebih efisien.

3. Hasil dari penilaian kinerja pegawai dari masing - masing kampus cabang STEKOM sudah terekap secara otomatis sehingga memudahkan bagian kepegawaian untuk mendapatkan data hasil penilaian kinerja setiap pegawai.

4. Pimpinan lebih cepat menerima laporan data hasil penilaian kinerja, sehingga data hasil penilaian dapat digunakan lebih cepat dalam mengambil kebijakan bagi pegawai seperti pertimbangan penyesuaian gaji, mutasi ataupun promosi jabatan.

\section{DAFTAR PUSTAKA}

Bekti, Bintu Humairah, 2015. "Mahir Membuat Website dengan Adobe Dreamweaver CS6, CSS dan JQuery”, Yogyakarta, ANDI.

Borg dan Gall, 1987. "Education Research An Introduction”, New York, Longman.

Budihardjo, 2015. "Panduan Praktis Penilaian Kinerja Karyawan”, Jakarta, Raih Asa Sukses (Penebar Swadaya Grup).

Heru Sulistiono, 2018. "Coding Mudah dengan CodeIgniter, Jquery, Bootstrap, dan Datatable", Jakarta, PT. Elex Media Komputindo.

Harison dan Roby, 2017. "Aplikasi Penilaian Kinerja Dosen pada Proses Belajar Mengajar Berbasis Web: Studi Kasus di Badan Penjamin Mutu Internal Institut Teknologi Padang”. Jurnal Teknologi dan Sistem komputer. 5(2): 89-93

Ilham Akhsanu Ridlo, 2017. "Panduan Pembuatan Flowchart"

Jublilee, 2016. "Pemograman Bootstrap Untuk Pemula", Jakarta, PT. Elex Media Komputindo.

Jublilee, 2016. "Trik Cepat Menguasahi Microsoft Visio”, Jakarta, PT. Elex Media Komputindo.

Miftahul Jannah, Sarwadi dan Cyber Creative, 2019. "Mahir Bahasa Pemograman PHP”, Jakarta, PT. Elex Media Komputindo.

Madcoms, 2016. "Pemograman PHP dan MySQL Untuk Pemula", Yogjakarta, CV. Andi.

Priyanto dan Hidayatullah, 2015. "Pemograman Web", Bandung, Informatika.

Purbadian, Yenda, 2016. "Trik Cepat Membangun Aplikasi Berbasis Web Dengan Framework Codelgniter", Yogyakarta, CV Andi Offset.

Ramdhani dan Arifansyah, 2018. "Perancangann Sistem Pendukung Keputusan Penilaian Kinerja Dosen Berbasis Web Menggunakan Metode SAW Pada STMIK-IM Bandung". Jurnal Teknologi dan Sistem Komputer. 10 (2).

Rismawati dan Mattalata, 2018. "Evaluasi Kinerja : Penilaian Kinerja Atas Dasar Prestasi Kerja Beriorientasi Kedepan", Makasar, Celebes Media Perkasa. 